\title{
PENGARUH PENAMBAHAN PLASTICIER GLISEROL TERHADAP KARAKTERISTIK HIDROGEL KITOSAN-GLUTARALDEHID UNTUK APLIKASI PENUTUP LUKA
}

\author{
Djony Izak Rudyardjo ${ }^{1)}$ \\ ${ }^{1)}$ PS Fisika Fakultas Sains dan Teknologi Universitas Airlangga, Surabaya \\ e-mail:djonyizak@gmail.com
}

\begin{abstract}
ABSTRAK
Telah dilakukan penelitian untuk mengetahui pengaruh penambahan plasticizer gliserol terhadap karakteristik hidrogel kitosan-glutaraldehid untuk aplikasi penutup luka. Penambahan gliserol bertujuan agar hidrogel kitosan-glutaraldehid lebih fleksibel dan memiliki sifat mekanik yang baik sehingga dapat diaplikasikan sebagai penutup luka sesuai dengan standar yang ada. Pembuatan hidrogel dilakukan dengan cara mencampurkan kitosan yang dilarutkan dalam $1 \%$ asam asetat dengan 1\% larutan glutaraldehid pada perbandingan $50: 3(\mathrm{v} / \mathrm{v})$ dan ditambahkan gliserol dengan variasi volume $1 \mathrm{ml}-4 \mathrm{ml}$. Konsentrasi gliserol yang digunakan tidak lebih dari $2 \%$. Berdasarkan penelitian yang telah dilakukan, penambahan gliserol menyebabkan ketebalan, kuat tarik, dan kemampuan mengabsorbsi cairan hidrogel menurun; elongasi dan ketahanan terhadap air hidrogel meningkat; serta struktur hidrogel menjadi lebih halus. Berdasarkan hasil uji sifat mekanik, hasil terbaik ditunjukkan oleh hidrogel kitosan-glutaraldehid-gliserol dengan penambahan gliserol $2 \%$ sebanyak $2 \mathrm{ml}$, yang memiliki nilai kuat tarik sebesar 14,34 $\pm 1,90 \mathrm{MPa}$ dan elongasi sebesar $2,40 \pm 0,91 \%$ yang memenuhi standar sifat mekanik kulit manusia. Struktur permukaan hidrogel tersebut halus, homogen, memiliki ketahanan terhadap air sebesar 24,78 \pm $6,57 \%$ serta mampu mengabsorbsi cairan lebih dari 99,9\% yaitu sebesar 149,65 $\pm 22,46 \%$ yang merupakan karakteristik penting hidrogel. Jadi, dapat disimpulkan bahwa hidrogel kitosanglutaraldehid-gliserol dengan penambahan gliserol 2\% sebanyak $2 \mathrm{ml}$ dapat diaplikasikan sebagai penutup luka.
\end{abstract}

Kata kunci: Glutaraldehid, Gliserol, Hidrogel, Kitosan, Penutup Luka, Plasticizer

\section{THE EFFECT OF ADDITION GLYCEROL AS PLASTICIER TO THE CHARACTERISTICS OF CHITOSAN-GLUTARALDEHYDE HIDROGEL FOR WOUND DRESSING APPLICATION}

\begin{abstract}
The research had been done to determine the effect of addition glycerol as plasticizer to the characteristics of chitosan-glutaraldehyde hydrogel for wound dressing application. The addition of glycerol was served to increase flexibility and improve the mechanical properties of chitosanglutaraldehyde hydrogel that can be applied as a wound dressing accordance with existing standards. Preparation of hydrogel was made by mixing chitosan dissolved in $1 \%$ acetic acid with $1 \%$ glutaraldehyde solution with ratio $50: 3(\mathrm{v} / \mathrm{v})$ and added by glycerol with variation of $1 \mathrm{ml}-4$ $\mathrm{ml}$. The glycerol concentration used no more than $2 \%$. Based on the research that had been done, the addition of glycerol caused thickness, tensile strength, and the absorption ability of hydrogel was decreased; elongation and water resistance of hydrogel increased; and the surface structure of hydrogel is more smooth. Based on the result of mechanical properties, the best characteristics of chitosan-glutaraldehyde-glycerol hydrogel is shown with the addition of $2 \mathrm{ml}$ glycerol $2 \%$ composition which has a value of tensile strength of 14,34 $\pm 1,90 \mathrm{MPa}$ and elongation at 2,40 \pm $0,91 \%$ that meet the standards of the mechanical properties of human skin. The structure of that hydrogel surface is smooth, homogeneous, has a water resistance of $24,78 \pm 6,57 \%$, and is able to absorb liquid more than $99,9 \%$ in the amount of $149,65 \pm 22,46 \%$ which is an important characteristic of the hydrogel. So, the chitosan-glutaraldehyde-glycerol hydrogel with the addition of $2 \mathrm{ml}$ glycerol $2 \%$ can be applied as a wound dressing.
\end{abstract}

Keywords : Chitosan, Glutaraldehyde, Glyserol, Hydrogel, Plasticizer, Wound Dressing 


\section{PENDAHULUAN}

Kulit merupakan organ aktif yang memiliki fungsi vital, yaitu sebagai perlindungan dan homeostasis tubuh. Secara alami, kulit merupakan organ imunologis yang penting dan mengandung seluruh elemen imunitas seluler. Namun meskipun setiap makhluk hidup memiliki fungsi biologis tersebut, ketika terdapat infeksi luka maka penyembuhan yang optimal juga perlu diupayakan seperti merawat atau menggunakan penutup luka yang telah dilapisi oleh bahan antimikroba. Penutup luka yang baik harus dapat memelihara lingkungan yang lembab di permukaan luka, memungkinkan pertukaran gas, bertindak sebagai penghalang bagi organisme, dan menghilangkan kelebihan eksudat (Jayakumar et. al., 2011).

Penggunaan kitosan sebagai bahan dasar untuk pembuatan material penutup luka sepertinya memang layak diunggulkan. Hasil penelitian yang telah dilakukan oleh Jayakumar et al, 2011. menunjukkan bahwa bahan berserat yang berasal dari kitin dan turunannya memiliki sifat ketahanan yang tinggi, biokompatibilitas, rendah toksisitas, dapat menyerap cairan, dan aktivitas antibakteri sehingga akan mempercepat penyembuhan. Selain sifat yang unggul dari kitosan di atas, kitosan ternyata juga memiliki kekurangan yaitu bersifat sensitif terhadap larutan asam. Oleh karena itu, penting untuk mencegah kitosan mudah larut dalam larutan asam dan meningkatkan ketahanan kimianya sekaligus hidrofilisitas serta degadrasi biologis jangka panjang. Hal tersebut dapat dilakukan dengan menghilangkan sejumlah gugus amina melalui reaksi silang namun tetap mempertahankan gugus amina bebasnya (Neto et. al., 2005). Salah satu senyawa yang biasa digunakan untuk reaksi silang adalah glutaraldehid.

Penelitian yang telah dilakukan oleh Rohindra et al., 2004 menunjukkan bahwa pencampuran kitosan dengan glutaraldehid dapat diaplikasikan sebagai hidrogel. Hidrogel adalah absorben alami yang mampu menyerap air hingga lebih dari 99\% kandungannya (Rohindra et al., 2004) serta dapat terurai melalui pembusukan oleh mikroba sehingga aman digunakan (Istiqomah, 2012). Sedangkan glutaraldehid merupakan suatu bahan desinfektan yang efektif dalam membasmi bakteri, virus serta jamur, dan bersifat nontoksik serta tidak iritatif bagi manusia (Widyatama, 2011). Studi yang dilakukan pada tikus dengan menggunakan ikatan silang antara kitosan dan glutaraldehid menunjukkan adanya toleransi yang menjanjikan pada jaringan hidup dari otot tikus (Jameela et. al., 1994).

Berdasarkan penelitian Istiqomah, 2012, bahwa pembuatan hidrogel kitosanglutaraldehid dengan perbandingan massa kitosan-glutaraldehid sebesar 50 : 3 memberikan hasil karakteristik yang baik dan dapat diaplikasikan sebagai penutup luka berdasarkan hasil uji in vivonya. Akan tetapi material tersebut masih bersifat agak rapuh sehingga belum dapat dilakukan uji sifat mekanik. Menurut Hu et al., 2012 kitosanglutaraldehid yang telah berikatan silang memiliki beberapa keterbatasan, seperti kerapuhan dan sifat penghalang udara yang rendah. Oleh sebab itu, maka perlu adanya penambahan plasticizer (zat pemlastis) untuk memperbaiki sifat mekaniknya mengingat penutup luka sebaiknya memiliki sifat mekanik yang baik agar dapat maksimal ketika diaplikasikan pada daerah yang mungkin banyak menyebabkan terjadinya deformasi akibat gesekan atau banyaknya pergerakan, seperti pada lutut, siku tangan, dan sebagainya. Zat pemlastis adalah suatu bahan yang ditambahkan ke dalam suatu material berupa elastomer untuk meningkatkan pengolahan, fleksibilitas, dan tarikannya. Suatu pemlastis dapat menurunkan viskositas lebur, temperatur transisi gelas, dan modulus elastis dari produk tanpa mengubah bentuk karakter kimia dari material pemlastis (Andreas, 1990). Salah satu bahan yang dapat digunakan sebagai zat pemlastis adalah gliserol. Gliserol merupakan zat pemlastis yang murah, sumbernya mudah diperoleh, dapat diperbaharui, serta ramah lingkungan karena mudah terdegradasi oleh alam. Penggunaan konsentrasi gliserol untuk lapisan tipis tidak lebih besar dari 2\% (Yudi, 2006; Cerquecira, 2009).

Berdasarkan hal tersebut maka penelitian yang dilakukan adalah pengaruh penambahan plasticizer gliserol terhadap karakteristik hidrogel kitosan-glutaraldehid untuk aplikasi penutup luka. Kitosan yang 
digunakan berasal dari kepiting karena kepiting memiliki prosentase kitin yang tinggi dibandingkan dengan organisme yang lain. Dengan adanya upaya perbaikan tersebut diharapkan nantinya dapat dihasilkan kualitas material hidrogel kitosanglutaraldehid yang lebih baik sehingga dapat bekerja secara optimal sebagai material medis.

\section{METODE PENELITIAN}

\section{Alat dan Bahan}

Alat

Neraca digital, petri disk, spatula, pipet, magnetic stirer, selotip, gelas beaker, gelas ukur, labu ukur, krus, kertas saring, kertas $\mathrm{pH}$, screen mesh, cutter, Coating Thickness Gauge tipe TT 210, spektrofotometer IR tipe Buck Scientific 500, spektroskopi IR tipe Thermo Scientific Nicolet iS10, mesin uji tarik merk IMADA tipe HV-1000N, dan mikroskop optik merk OLYMPUS tipe SZX9 dengan kamera perekam merk SONY ExwaveHAD.

Bahan

Cangkang kepiting, glutaraldehid, gliserol, Phosphate Buffer Saline (PBS), larutan $\mathrm{HCl}$, larutan $\mathrm{NaOH}$, asam asetat, dan aquades.

\section{Tahap Pembuatan Kitosan}

\section{a. Tahap Deproteinasi}

Cangkang kepiting yang sudah dihaluskan dimasukkan ke dalam gelas beaker dan ditambahkan dengan natrium hidroksida $3,5 \%$ dengan perbandingan 1:10 (w/v). Proses deproteinasi dilakukan selama \pm 2 jam pada suhu $75^{\circ} \mathrm{C}$ dengan pengadukan magnetic stirer. Cangkang kepiting dicuci dengan menggunakan aquades hingga $\mathrm{pH}$ air cucian netral kemudian dikeringkan dalam oven pada suhu $80^{\circ} \mathrm{C}$ sampai kering. Dalam proses ini didapatkan crude kitin.

b. Tahap Demineralisasi

Crude kitin dimasukkan ke dalam gelas beaker kemudian ditambahkan larutan $\mathrm{HCl}$ $2 \mathrm{~N}$ sedikit demi sedikit agar busa yang dihasilkan tidak tumpah, dengan perbandingan antara crude kitin dengan larutan $\mathrm{HCl} 1: 15 \%$ (w/v). Pada proses ini dilakukan pengadukan menggunakan magnetic stirer selama 30 menit pada suhu kamar. Setelah itu crude kitin dicuci dengan aquades hingga $\mathrm{pH}$ air cucian netral, kemudian dikeringkan dalam oven pada suhu $80^{\circ} \mathrm{C}$ sampai kering. Dalam proses ini akan menghasilkan kitin.

c. Tahap Deasetilasi

Proses ini dilakukan dengan cara memasukkan kitin ke dalam gelas beaker, kemudian ditambahkan larutan $\mathrm{NaOH}$ 60\% dengan perbandingan kitin dan larutan $\mathrm{NaOH}$ 1:10 (w/v). Campuran direbus dengan suhu $110^{\circ} \mathrm{C}$ selama 2 jam dengan pengadukan menggunakan magnetic stirer. Setelah itu campuran disaring, kemudian dicuci dengan aquades hingga didapatkan $\mathrm{pH}$ air cucian netral. Langkah selanjutnya adalah dengan mengeringkannya di dalam oven pada suhu $80{ }^{\circ} \mathrm{C}$ sampai kering, sehingga diperoleh kitosan. Kitosan yang diperoleh kemudian ditimbang dan dicatat.

\section{Tahap Pembuatan Hidrogel Kitosan- Glutaraldehid-Gliserol}

a. Tahap Pembuatan Larutan Kitosan

Kitosan dilarutkan ke dalam asam asetat $1 \%$ pada temperatur ruang dan diaduk selama \pm 5 jam dengan menggunakan magnetic stirer untuk mendapatkan larutan $1 \% \quad(\mathrm{w} / \mathrm{v})$. Larutan kitosan kental berwarna kuning pucat kemudian didiamkan selama semalam untuk menghilangkan gelembung.

b. Tahap Pembuatan Hidrogel

$$
\text { Larutan glutaraldehid } 1 \%
$$

ditambahkan ke dalam larutan kitosan $1 \%$ dengan rasio $50: 3(\mathrm{v} / \mathrm{v})$. Larutan tersebut diaduk selama 1 jam dalam suhu ruang sampai viskositasnya meningkat. Larutan kemudian ditambahkan $1 \mathrm{ml}$ gliserol $1 \%$ sambil diaduk selama $1 \mathrm{jam}$. Hidrogel yang terbentuk kemudian dituang pada petri disk sebanyak $52 \mathrm{ml}$ dan dikeringkan dalam suhu ruang selama 10 hari (dengan keadaan lingkungan steril). Perlakuan tersebut kemudian diulangi untuk penambahan gliserol masing-masing $2 \mathrm{ml}, 3 \mathrm{ml}$, dan $4 \mathrm{ml}$ serta untuk konsentrasi gliserol $2 \%$.

Hidrogel kitosan-glutaraldehidgliserol yang terbentuk kemudian dikarakterisasi untuk mengetahui karakteristik terbaik hidrogel yang dapat diaplikasikan sebagai penutup luka, meliputi uji ketebalan, uji tarik, uji morfologi, uji gugus FT-IR, uji ketahanan terhadap air, dan uji kemampuan absorbsi hidrogel. 


\section{Uji Ketebalan dan Uji Tarik}

Uji ketebalan dilakukan dengan mengukur ketebalan pada tiga titik yang berbeda dan sistematis agar dapat mewakili ketebalan seluruh sampel kemudian dihitung ketebalan rata-ratanya. Sedangkan uji tarik dilakukan dengan membentuk sampel terlebih dahulu sesuai standar yang digunakan lalu sampel ditarik hingga putus sehingga didapatkan data berupa gaya yang diberikan dan pertambahan panjang sampel. Data tersebut kemudian diolah menjadi kuat tarik $(\sigma)$ dan elongasi $(\Sigma)$ dengan persamaan sebagai berikut (Van Vlack, 1991):

$\sigma=\frac{F}{A}$

dimana $\mathrm{F}$ adalah gaya tarikan dan $\mathrm{A}$ adalah luas penampang spesimen.

$\varepsilon=\frac{\Delta \mathrm{L}}{\mathrm{Lo}} \times 100 \%=\frac{\mathrm{L}-\mathrm{Lo}}{\mathrm{Lo}} \times 100 \%$

dimana $\Delta \mathrm{L}$ adalah perubahan panjang benda dan Lo adalah panjang benda mula-mula.

\section{Uji Morfologi}

Pengujian dilakukan dengan cara memotong sampel dengan ukuran $1 \mathrm{~cm} \times 1 \mathrm{~cm}$, kemudian meletakkan sampel tersebut di atas preparat dan diamati sehingga dapat terlihat struktur permukaan hidrogel kitosanglutaraldehid-gliserol.

\section{Uji Gugus FT-IR}

Uji spektroskopi IR untuk kitosan dilakukan dengan cara menggerus kitosan bersama $\mathrm{KBr}$ dengan perbandingan 1:10 (w/w). Digunakan $\mathrm{KBr}$ karena tempat sel cuplikan dari sampel harus terbuat dari bahan-bahan yang tembus sinar inframerah seperti $\mathrm{NaCl}$ dan $\mathrm{KBr}$. Campuran kemudian dipres dengan menggunakan alat pengepres pada tekanan 10 torr sehingga menjadi pellet yang padat. Sedangkan untuk uji spektroskopi IR hidrogel kitosanglutaraldehid-gliserol cukup dilakukan dengan meletakkan hidrogel pada tempat sampel alat spektroskopi. Hasil IR diperoleh dalam bentuk spektrum yang menggambarkan besarnya nilai \% transmitan dan bilangan gelombang sehingga dapat diketahui gugus fungsi apa saja yang terdapat pada kitosan dan hidrogel kitosanglutaraldehid-gliserol.

\section{Uji Ketahanan Terhadap Air}

Pengujian dilakukan dengan cara mengukur berat awal (Wo) sampel yang berukuran $1 \mathrm{~cm} \times 1 \mathrm{~cm}$ kemudian direndam dalam aquades selama 15 menit (Wardhani, 2012). Sampel yang telah direndam kemudian disaring dengan menggunakan kertas saring dan diukur lagi berat akhirnya (Wa) sehingga diperoleh prosentase air yang diserap dengan menggunakan persamaan berikut (Wardhani, 2012):

$\%$ Air yang diserap $=\frac{W_{a}-W_{o}}{W_{o}} \times 100 \%$

Uji Kemampuan Absorbsi Hidrogel

Kemampuan absorbsi dari hidrogel ditentukan dengan menginkubasi hidrogel pada pH 7,4 di Phosphate Buffer Saline (PBS) pada suhu ruang. Larutan PBS dibuat dengan cara melarutkan 1 tablet PBS ke dalam 100 $\mathrm{ml}$ aquades dan diaduk hingga larut. Pengujian dilakukan dengan cara mengukur berat awal $\left(m_{o}\right)$ sampel yang berukuran $1 \mathrm{~cm}$ $\mathrm{x} 1 \mathrm{~cm}$ kemudian direndam dalam larutan PBS selama 3 jam (Baran, et. al., 2012). Sampel yang telah direndam kemudian disaring dengan menggunakan kertas saring dan diukur lagi berat akhirnya $\left(m_{e}\right)$. Banyaknya air yang terserap pada hidrogel dapat dihitung menggunakan persamaan berikut (Singh, et. al., 2005):

$E=\frac{m_{e}-m_{o}}{m_{o}} \times 100 \%$

\section{HASIL DAN PEMBAHASAN}

\section{Hasil Pembuatan Kitosan}

Dari 70,0015 gram serbuk cangkang kepiting yang digunakan pada proses pembuatan kitosan, meliputi proses deproteinasi, proses demineralisasi, dan proses deasetilasi, diperoleh kitosan sebanyak 5,2305 gram. Untuk mengetahui bahwa produk yang dihasilkan dari proses tersebut adalah kitosan maka dilakukan uji spektrokopi IR.

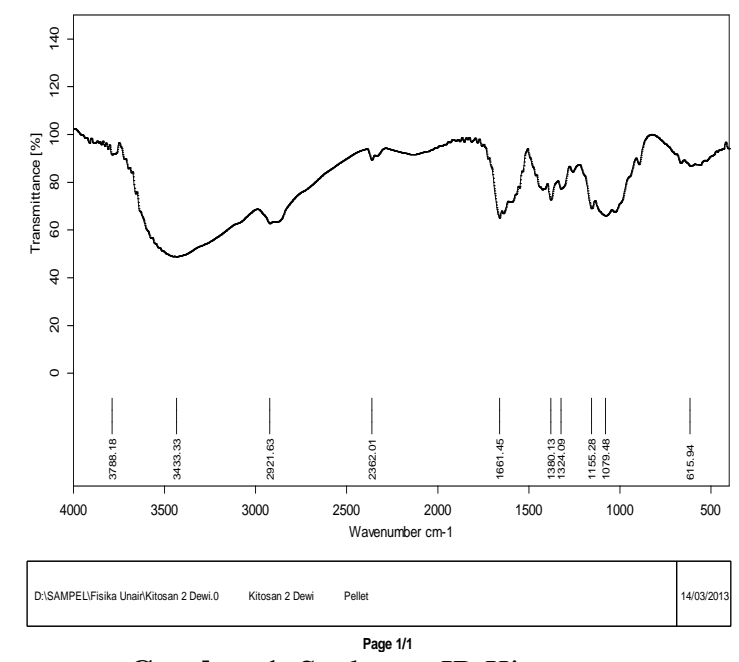

Gambar 1. Spektrum IR Kitosan 
Dari spektrum IR di atas diketahui bahwa bahan kitosan menunjukkan gugus serapan karaktetristik. Pada spektrum IR tersebut terlihat adanya pita tajam yang khas pada gugus karboksil amida $(\mathrm{C}=\mathrm{O}$ amida $)$ di daerah $1661,45 \mathrm{~cm}^{-1}$. Selain itu juga terdapat puncak pita serapan gugus hidroksil $(\mathrm{O}-\mathrm{H})$ pada daerah $3433,33 \mathrm{~cm}^{-1}$, gugus $\mathrm{C}-\mathrm{H}$ pada daerah 2921,63 $\mathrm{cm}^{-1}$, dan gugus C-O pada daerah 1300-1000 $\mathrm{cm}^{-1}$. Berdasarkan analisis gugus fungsi tersebut, spektrum IR kitosan menunjukkan munculnya serapan karakteristik sehingga dapat disimpulkan produk preparasi pada penelitian ini adalah kitosan. Penghitungan derajat deasetilasi (DD) kitosan menggunakan spektrum IR ditentukan oleh absorbansi dari gugus amida dan gugus $\mathrm{OH}$. Berdasarkan analisis data spektrum IR yang telah dilakukan, dengan menggunakan metode base line, maka diperoleh derajat deasetilasi kitosan sebesar $81,92 \%$. Standar nilai untuk derajat deasetilasi kitosan adalah DD $\geq 70 \%$ (Suptijah, et. al., 1992).

\section{Hasil Pembuatan Hidrogel Kitosan- Glutaraldehid-Gliserol \\ Selama proses pengeringan terjadi} reaksi antara kitosan dengan glutaraldehid berupa ikat silang serta reaksi antara kitosanglutaraldehid-gliserol dalam membentuk hidrogel. Volume hidrogel kitosanglutaraldehid-gliserol yang semula $52 \mathrm{ml}$ untuk semua variasi volume gliserol menyusut menjadi lembaran tipis hidrogel.

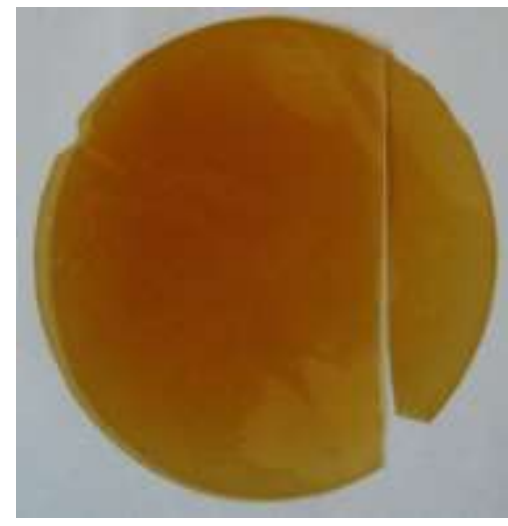

Gambar 2. Spektrum IR Kitosan

Adanya penyusutan atau pengurangan massa yang cukup signifikan ini dikarenakan oleh proses ikat silang antara kitosan dengan glutaraldehid yang menyebabkan lepasnya molekul asam asetat dalam matriks polimer, sehingga dapat disimpulkan telah terjadi penurunan kadar pengembangan selama proses sintesis ikat silang kitosan (Baroni, et .al., 2008). Selain terjadi penyusutan volume hidrogel kitosanglutaraldehid-gliserol, selama proses pengeringan tersebut hidrogel yang dicetak juga mengalami perubahan warna dari bening menjadi kuning tua. Adanya perubahan warna ini menunjukkan secara visual adanya pembentukan ikatan silang antara kitosanglutaraldehid (Monteiro and Airoldi, 1999).

Hasil Uji Ketebalan

Tabel 1. Data Pengukuran Tebal Hidrogel Kitosan-Glutaraldehid-Gliserol

\begin{tabular}{ccc}
$\begin{array}{c}\text { Konsentrasi } \\
\text { Gliserol (\%) }\end{array}$ & $\begin{array}{c}\text { Variasi } \\
\text { Gliserol }(\mathbf{m l})\end{array}$ & $\begin{array}{c}\text { Tebal } \\
\text { Rata-Rata } \\
(\boldsymbol{\mu m})\end{array}$ \\
\hline 1 & 1 & $70,6 \pm 0,6$ \\
& 2 & $69,5 \pm 1,9$ \\
3 & $64,5 \pm 1,5$ \\
& 4 & $62,2 \pm 1,2$ \\
2 & 1 & $76,6 \pm 1,9$ \\
& 2 & $75,6 \pm 1,0$ \\
& 3 & $74,8 \pm 2,5$ \\
& 4 & $74,3 \pm 2,2$ \\
\hline
\end{tabular}

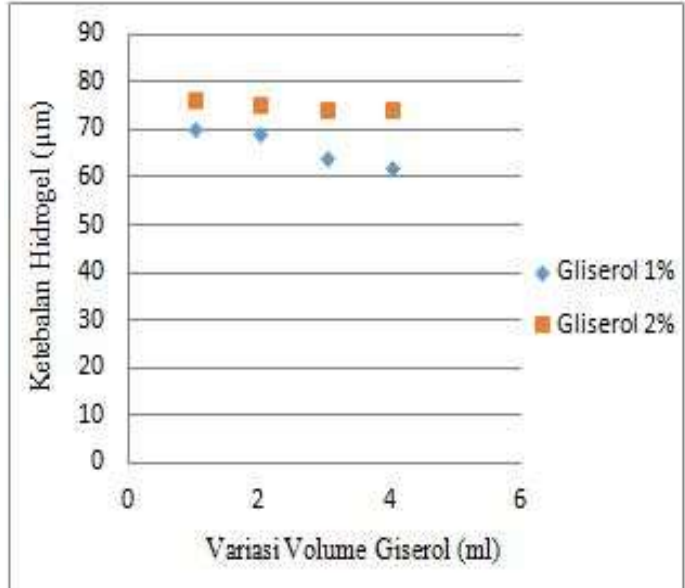

Gambar 3. Pengaruh Variasi Gliserol Terhadap Tebal Rata-Rata Hidrogel KitosanGlutaraldehid-Gliserol

Gambar 3 menunjukkan bahwa ketebalan hidrogel kitosan-glutaraldehidgliserol menurun seiring dengan meningkatnya penambahan volume gliserol pada konsentrasi yang sama. Penurunan ketebalan ini disebabkan karena molekul pemlastis larut dalam tiap-tiap rantai polimer sehingga akan mempermudah gerakan molekul polimer yang menyebabkan pemlastis dapat menyebar ke rantai polimer 
tersebut yang dapat mengurangi gaya gesekan dan membentuk ikatan polimer-pemlastis. Hal ini memungkinkan karena pemlastis sering digunakan untuk meningkatkan fleksibilitas film dengan mengurangi ikatan hidrogen intramolekular antar rantai polimer sehingga meningkatkan jarak antar intramolekular tersebut (Janjarasskul and Krochta, 2010). Dengan meningkatnya jarak atau ruang intramolekular antar rantai polimer maka tentu saja polimer yang terbentuk akan lebih terdistribusi merata dan fleksibel sehingga menurunkan ketebalan polimer itu sendiri. Menurut McHugh et al., 1994, penambahan pemlastis dengan konsentrasi yang lebih tinggi pada film sodium kaseinat juga menurunkan ketebalan.

Hasil Uji Tarik

Tabel 2. Data Pengukuran Sifat Mekanik Hidrogel Kitosan-Glutaraldehid-Gliserol

\begin{tabular}{|c|c|c|c|}
\hline $\begin{array}{c}\text { Konsen } \\
\text { trasi } \\
\text { Gliserol } \\
(\boldsymbol{\%})\end{array}$ & $\begin{array}{c}\text { Variasi } \\
\text { Gliserol } \\
(\mathbf{m l})\end{array}$ & $\begin{array}{c}\text { Kuat Tarik } \\
\mathbf{( M P a})\end{array}$ & $\begin{array}{c}\text { Elongasi } \\
\mathbf{( \% )}\end{array}$ \\
\hline 1 & 1 & $62,95 \pm 5,98$ & $1,27 \pm 0,85$ \\
\hline & 2 & $60,89 \pm 16,68$ & $1,69 \pm 0,86$ \\
\hline & 3 & $51,08 \pm 11,91$ & $1,67 \pm 0,84$ \\
\hline & 4 & $30,96 \pm 6,01$ & $1,75 \pm 0,87$ \\
\hline 2 & 1 & $29,58 \pm 2,35$ & $2,22 \pm 0,89$ \\
\hline & 2 & $14,34 \pm 1,90$ & $2,40 \pm 0,91$ \\
\hline & 3 & - & - \\
\hline & 4 & - & - \\
\hline
\end{tabular}

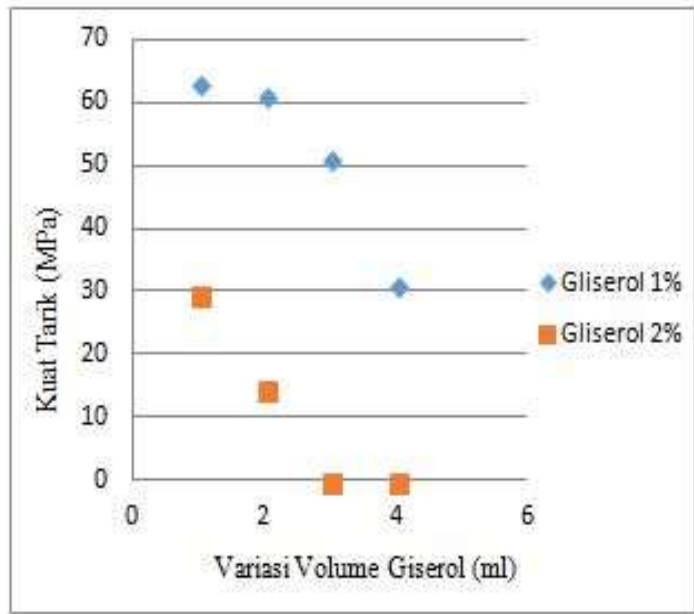

Gambar 4. Pengaruh Variasi Gliserol Terhadap Kuat Tarik Hidrogel KitosanGlutaraldehid-Gliserol

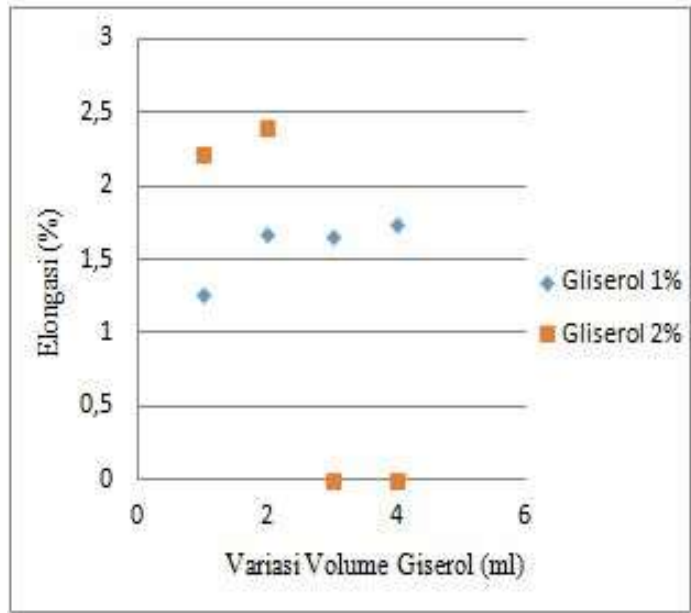

Gambar 5. Pengaruh Variasi Gliserol Terhadap Elongasi Hidrogel KitosanGlutaraldehid-Gliserol

Gambar 4 menunjukkan bahwa dengan meningkatnya volume dan konsentrasi gliserol yang ditambahkan pada hidrogel kitosan-glutaraldehid maka nilai kuat tarik dari hidrogel tersebut semakin menurun. Untuk hidrogel dengan penambahan gliserol $2 \%$ sebanyak $3 \mathrm{ml}$ dan 4 ml tidak dapat dilakukan uji tarik karena hidrogel tersebut sangat lengket dan tidak dapat dipreparasi. Hal ini disebabkan karena penambahan gliserol yang berlebih akan menyebabkan lapisan tipis menjadi lunak dan lengket sehingga sukar diangkat dari cetakan karena gliserol lebih bersifat mengikat air dan melunakkan permukaan. Selain itu, penambahan gliserol yang sudah melebihi batas plastisasi menyebabkan molekul pemlastis yang berlebih berada pada fase tersendiri diluar fase hidrogel (Harsunu, 2008). Keadaan tersebut mengakibatkan penurunan gaya intermolekul antar rantai. Penambahan plasticizer yang berlebihan akan menyebabkan plastisasi tidak efisien lagi (Kemalsari, 2010).

Menurut Park et al., 2001, bentuk, jumlah atom karbon dalam rantai, dan jumlah gugus hidroksil yang terdapat pada molekul plasticizer akan mempengaruhi sifat mekanik (kuat tarik dan elongasi) suatu film. Plasticizer akan menurunkan ikatan hidrogen dalam film sehingga meningkatkan fleksibilitas dari film dimana dengan meningkatnya fleksibilitas maka kuat tarik dari film tersebut akan semakin kecil (Krochta, 1994). Selain itu, berkurangnya gaya antarmolekul tersebut juga 
menyebabkan struktur film yang dibentuk menjadi lebih halus dan fleksibel. Hal ini memungkinkan karena gliserol merupakan molekul hidrofilik kecil yang dapat dengan mudah masuk di antara rantai molekul dan membentuk ikatan hidrogen amida dengan protein sehingga terjadi ikatan silang antara kitosan dengan gliserol yang mampu memperbaiki sifat mekanik film dibandingkan dengan film tanpa penambahan gliserol (Harsunu, 2008). Hal ini sesuai dengan yang ditunjukkan oleh Gambar 5, dimana dengan meningkatnya volume dan konsentrasi plasticizer gliserol yang ditambahkan pada hidrogel kitosanglutaraldehid maka elongasi dari hidrogel tersebut akan semakin meningkat pula dengan nilai kuat tarik yang semakin menurun.

Hidrogel kitosan-glutaraldehidgliserol dapat digunakan sebagai material medis sebagai penutup luka jika memenuhi standar sifat mekanik tertentu yang mendekati sifat mekanik kulit. Menurut Svensson et al., 2011, standar mekanik kulit untuk tendon memiliki nilai kuat tarik antara 5-15 MPa. Sedangkan menurut Maganaris et al., 1999, standar mekanik kulit untuk tumit memiliki nilai kuat tarik antara 0,3-25 $\mathrm{MPa}$ dan elongasi antara 1-25 \%. Berdasarkan analisis data yang telah dilakukan, maka hidrogel kitosan-glutaraldehid-gliserol dengan perbandingan 50:3:2 (v/v) untuk konsentrasi gliserol $2 \%$ dipilih sebagai sampel terbaik karena memiliki nilai kuat tarik sebesar 14,34 $\pm 1,90 \mathrm{MPa}$ dan elongasi sebesar 2,40 $\pm 0,91 \%$ sehingga masuk dalam range sebagai material medis penutup luka yang mendekati sifat mekanik kulit menurut Svensson et al., 2011dan Maganaris et al., 1999, dimana penutup luka tersebut dapat diaplikasikan pada tendon dan tumit manusia.
Hasil Uji Morfologi

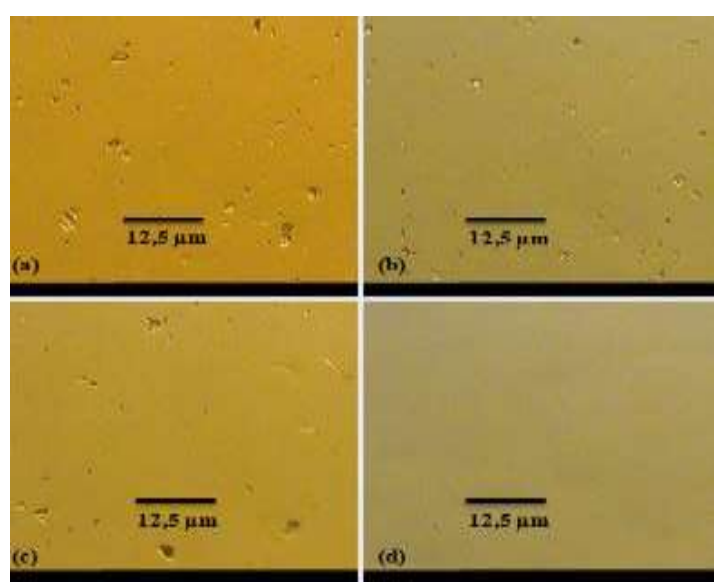

Gambar 6. Hasil Uji Morfologi Permukaan Hidrogel Kitosan-Glutaraldehid-Gliserol dengan Konsentrasi Gliserol 1\% dan Variasi Penambahan Gliserol : (a) $1 \mathrm{ml}$ (b) $2 \mathrm{ml}$ (c) 3 $\mathrm{ml}$ (d) $4 \mathrm{ml}$. Perbesaran 57x

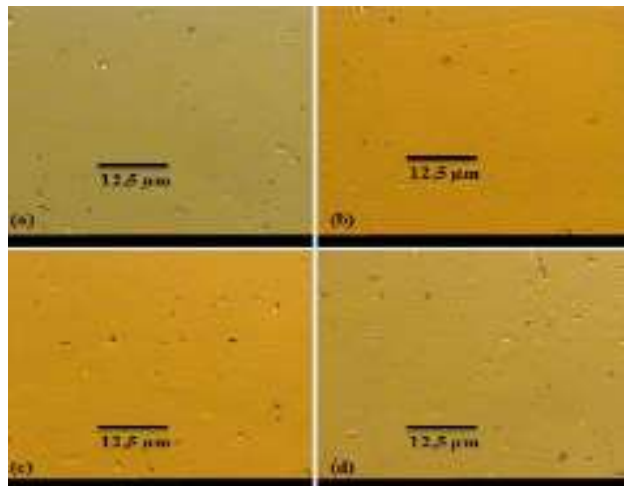

Gambar 7. Hasil Uji Morfologi Permukaan Hidrogel Kitosan-Glutaraldehid-Gliserol dengan Konsentrasi Gliserol 2\% dan Variasi Penambahan Gliserol : (a) $1 \mathrm{ml}$ (b) $2 \mathrm{ml}$ (c) $3 \mathrm{ml}$ (d) $4 \mathrm{ml}$. Perbesaran 57x

Pada pembahasan sebelumnya telah dijelaskan bahwa penambahan plasticizer akan menyebabkan struktur film yang dibentuk menjadi lebih halus dan fleksibel. Hal ini terlihat pada Gambar 6 dimana dengan semakin meningkatnya volume plasticizer gliserol yang ditambahkan maka struktur permukaan juga terlihat lebih halus dibandingkan yang lain, tetapi hal ini tidak terlihat pada Gambar 7. Adanya perbedaan tersebut dikarenakan penambahan plasticizer gliserol telah melebihi batas kompatibel sehingga menyebabkan plastisasi tidak efisien lagi (Kemalasari, 2010). Penambahan gliserol yang sudah melebihi batas plastisasi menyebabkan molekul pemlastis yang berlebih berada pada fase tersendiri diluar 
fase hidrogel (Harsunu, 2008). Hal ini dapat terlihat pada Gambar 7, dimana struktur permukaannya kurang halus dan terlihat kurang homogen dalam persebaran masingmasing komposisinya.

\section{Hasil Uji FT-IR}

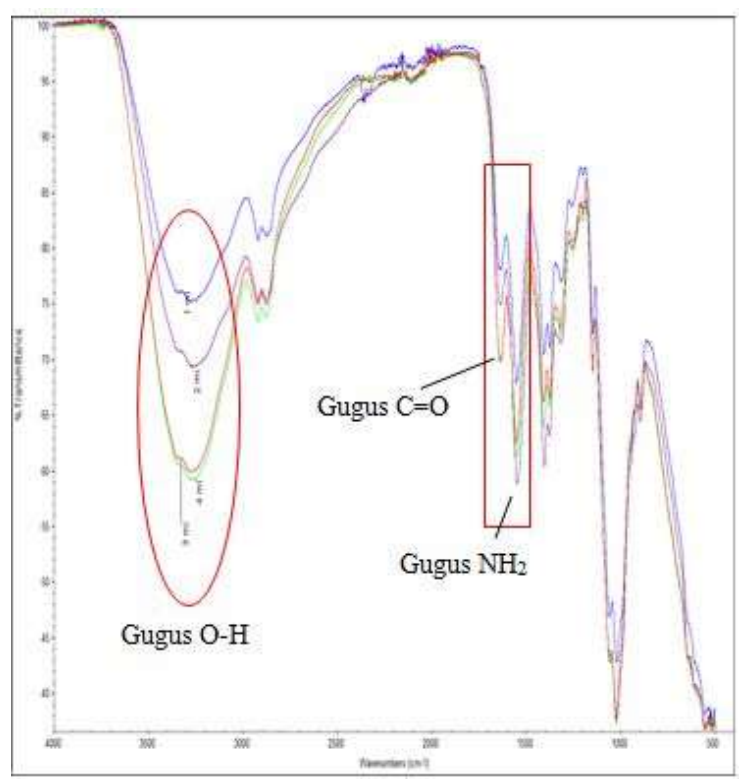

Gambar 8. Hasil Uji FT-IR Kitosan-

Glutaraldehid-Gliserol untuk Konsentrasi Gliserol $1 \%$

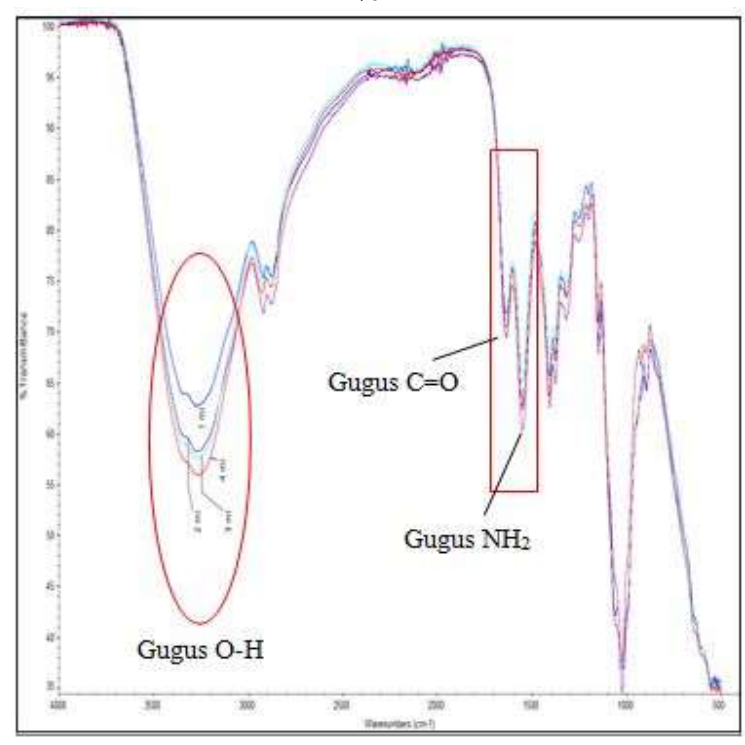

Gambar 9. Hasil Uji FT-IR Kitosan-

Glutaraldehid-Gliserol untuk Konsentrasi Gliserol $2 \%$

Berdasarkan hasil spektroskopi IR hidrogel kitosan-glutaraldehid-gliserol yang didapat dari berbagai variasi komposisi volume gliserol di atas, terlihat adanya interaksi antara kitosan-glutaraldehid-gliserol dalam membentuk hidrogel. Hal ini dapat dilihat dari adanya perubahan serapan yang terjadi pada daerah bilangan gelombang $3500-3330 \mathrm{~cm}^{-1}$ yang merupakan gugus $\mathrm{O}-\mathrm{H}$. Selain itu, daerah bilangan gelombang 1820$1540 \mathrm{~cm}^{-1}$ yang merupakan gugus $\mathrm{C}=\mathrm{O}$ dan daerah bilangan gelombang $1730-1580 \mathrm{~cm}^{-1}$ yang merupakan gugus $\mathrm{NH}_{2}$ identik satu sama lain. Dengan semakin meningkatnya volume gliserol yang ditambahkan maka persen gugus $\mathrm{O}-\mathrm{H}$ yang ditransmisikan semakin berkurang, yang berarti gugus tersebut banyak mengalami ikat silang. Hal ini memungkinkan karena selain kitosan mengalami ikat silang dengan glutaraldehid (ikat silang terjadi pada gugus $\mathrm{C}=\mathrm{O}$ dan gugus $\mathrm{NH}_{2}$ [3]), kitosan juga mengalami ikat silang dengan gliserol melalui interaksi antara gugus hidroksil kitosan dan gliserol oleh ikatan hidrogen (Leceta and Guerrero, 2012).

Selain gugus $\mathrm{O}-\mathrm{H}$, gugus $\mathrm{NH}_{2}$, dan gugus $\mathrm{C}=\mathrm{O}$, gugus fungsi lain yang terdapat dalam hidrogel kitosan-glutaraldehid-gliserol ini adalah gugus ester (C-O) pada daerah bilangan gelombang 1300-1000 $\mathrm{cm}^{-1}$. Dengan dimilikinya gugus fungsi tersebut maka film bersifat dapat terdegradasi (Darni, et. al., 2009). Penambahan variasi volume gliserol bertujuan untuk mengetahui gugus fungsi yang terbentuk akibat dari pencampuran antara kitosan-glutaraldehid-gliserol yang membentuk hidrogel. Tetapi jika dilihat dari analisis hasil spektroskopi IR hidrogel kitosan-glutaraldehid-gliserol, belum ada gugus fungsi baru yang terbentuk. Hal ini berarti hidrogel kitosan-glutaraldehid-gliserol yang dihasilkan merupakan proses mechanical mixture sehingga hidrogel tersebut memiliki sifat seperti komponen penyusunnya.

\section{Hasil Uji Ketahanan Terhadap Air}

Tabel 3. Data Pengukuran Rata-Rata Ketahanan Hidrogel Kitosan-Glutaraldehid-Gliserol terhadap Air

\begin{tabular}{ccc}
\multicolumn{3}{c}{ Air } \\
\hline $\begin{array}{c}\text { Konsentrasi } \\
\text { Gliserol (\%) }\end{array}$ & $\begin{array}{c}\text { Variasi } \\
\text { Gliserol }(\mathbf{m l})\end{array}$ & $\begin{array}{c}\text { Air yang } \\
\text { Diserap }(\%)\end{array}$ \\
\hline 1 & 1 & $59,46 \pm 16,18$ \\
& 2 & $51,06 \pm 12,18$ \\
3 & $41,11 \pm 15,60$ \\
4 & $37,23 \pm 9,38$ \\
& 1 & $36,73 \pm 11,52$ \\
2 & 2 & $24,78 \pm 6,57$ \\
& 3 & $36,71 \pm 7,75$ \\
& 4 & $2,59 \pm 1,32$ \\
\hline
\end{tabular}




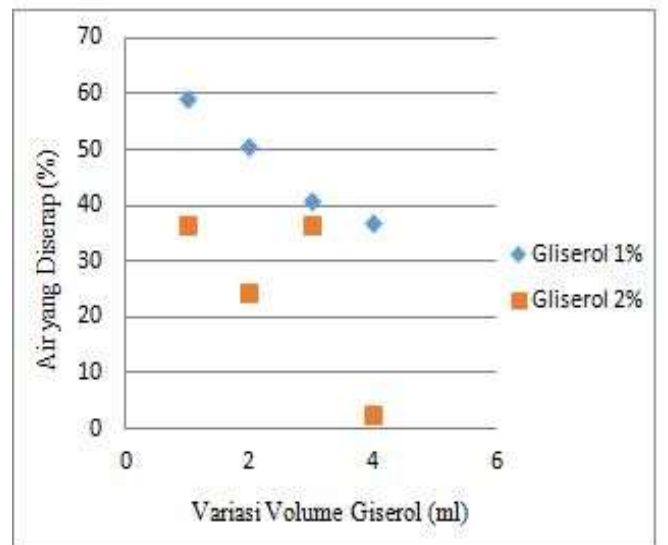

Gambar 10. Pengaruh Variasi Gliserol Terhadap Persen Air yang Diserap Hidrogel KitosanGlutaraldehid-Gliserol

Gambar 10 menunjukkan bahwa dengan meningkatnya volume dan konsentrasi gliserol yang ditambahkan pada hidrogel kitosan-glutaraldehid maka nilai ketahanan hidrogel tersebut terhadap air semakin menurun. Adanya penurunan penyerapan air tersebut dikarenakan semakin banyak gliserol yang ditambahkan ke dalam campuran hidrogel maka akan semakin banyak pula gliserol yang berikatan silang dengan gugus $\mathrm{O}-\mathrm{H}$ yang dimiliki hidrogel kitosan-glutaraldehid. Hal ini didukung oleh hasil FT-IR dari hidrogel dimana dengan semakin meningkatnya gliserol yang ditambahkan maka persen gugus $\mathrm{O}-\mathrm{H}$ yang ditransmisikan semakin kecil, yang berarti gugus tersebut telah banyak mengalami ikat silang. Banyaknya gugus $\mathrm{O}-\mathrm{H}$ yang dimiliki sangat memungkinkan film untuk berikatan dengan air (Darni, et. al., 2009), sehingga jika semakin banyak gugus $\mathrm{O}-\mathrm{H}$ yang mengalami ikat silang maka kemampuan suatu film untuk berikatan dengan air semakin menurun.

\section{Hasil Uji Kemampuan Absorbsi}

Tabel 4. Data Pengukuran Rata-Rata Kemampuan Absorbsi Hidrogel Kitosan-Glutaraldehid-Gliserol

\begin{tabular}{ccc}
\hline $\begin{array}{c}\text { Konsentrasi } \\
\text { Gliserol (\%) }\end{array}$ & $\begin{array}{c}\text { Variasi } \\
\text { Gliserol }(\mathbf{m l})\end{array}$ & $\begin{array}{c}\text { Air yang } \\
\text { Diserap }(\%)\end{array}$ \\
\hline 1 & 1 & $268,21 \pm 10,80$ \\
& 2 & $260,46 \pm 25,83$ \\
& 3 & $116,51 \pm 9,38$ \\
2 & 1 & $50,12 \pm 5,96$ \\
& 2 & $178,97 \pm 6,82$ \\
& 3 & $149,65 \pm 22,46$ \\
& 4 & $105,05 \pm 5,46$ \\
& & $144,44 \pm 16,19$ \\
\hline
\end{tabular}

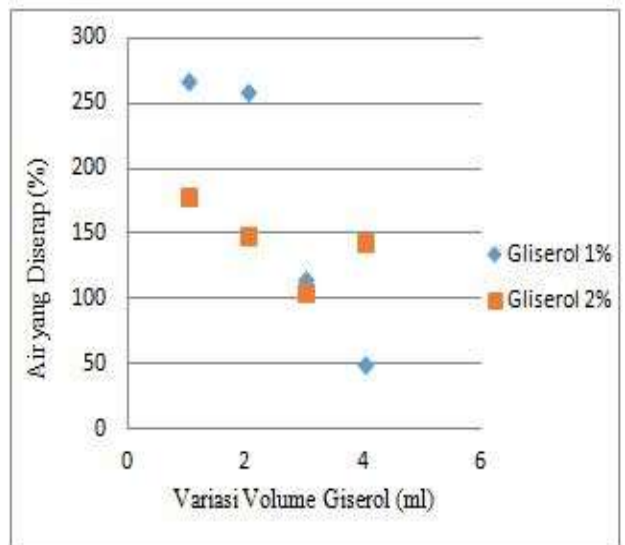

Gambar 11. Pengaruh Variasi Gliserol Terhadap Kemampuan Absorbsi Hidrogel KitosanGlutaraldehid-Gliserol

Hidrogel merupakan suatu jaringan rantai polimer hidrofilik yang saling terikat silang satu sama lain dan memiliki kemampuan absorbsi yang tinggi hingga lebih dari 99,9\% (Erizal, et. al., 2010). Gambar 11 menunjukkan bahwa dengan meningkatnya volume dan konsentrasi gliserol yang ditambahkan pada hidrogel kitosan-glutaraldehid maka nilai kemampuan hidrogel tersebut untuk mengabsorbsi cairan semakin menurun, namun masih dapat disebut sebagai hidrogel dari segi kemampuan absorbsinya, kecuali untuk hidrogel dengan penambahan gliserol $1 \%$ sebanyak $4 \mathrm{ml}$. Sama seperti uji ketahanan hidrogel terhadap air, adanya penurunan kemampuan absorbsi hidrogel tersebut dikarenakan semakin banyak gliserol yang ditambahkan ke dalam campuran hidrogel maka akan semakin banyak pula gliserol yang berikatan silang dengan gugus $\mathrm{O}-\mathrm{H}$ yang dimiliki hidrogel kitosan-glutaraldehid. Hal ini didukung oleh hasil FT-IR dari hidrogel dimana dengan semakin meningkatnya gliserol yang ditambahkan maka persen gugus O-H yang ditransmisikan semakin kecil, yang berarti gugus tersebut telah banyak mengalami ikat silang. Banyaknya gugus $\mathrm{O}-\mathrm{H}$ yang dimiliki sangat memungkinkan film untuk berikatan dengan air (Darni, et. al., 2009), sehingga jika semakin banyak gugus $\mathrm{O}-\mathrm{H}$ yang mengalami ikat silang maka kemampuan suatu film untuk berikatan dengan air semakin menurun. 


\section{KESIMPULAN}

Penambahan plasticizer gliserol dengan variasi $1 \mathrm{ml}-4 \mathrm{ml}$ untuk konsentrasi gliserol $1 \%$ dan gliserol $2 \%$ berpengaruh pada karakteristik sifat mekanik dan sifat fisik hidrogel kitosan-glutaraldehid-gliserol. Penambahan ini menyebabkan ketebalan menurun, kuat tarik menurun, kemampuan absorbsi cairan hidrogel menurun, elongasi meningkat, ketahanan hidrogel terhadap air meningkat, serta struktur permukaan hidrogel semakin halus. Karakteristik hidrogel kitosan-glutaraldehid-gliserol yang terbaik karena memenuhi standar untuk diaplikasikan sebagai penutup luka ditunjukkan oleh hidrogel dengan penambahan gliserol $2 \%$ sebanyak $2 \mathrm{ml}$ dimana hidrogel ini memiliki ketebalan sebesar 75,6 $\pm 1,0$, kuat tarik sebesar 14,34 $\pm 1,90 \mathrm{MPa}$, elongasi sebesar $2,40 \pm 0,91 \%$, ketahanan terhadap air sebesar $24,78 \pm 6,57$, mampu mengabsorbsi cairan sebesar $149,65 \pm 22,46$, serta struktur permukaannya halus dan homogen sehingga dapat diaplikasikan sebagai penutup luka.

\section{UCAPAN TERIMA KASIH}

Pada kesempatan ini penulis ingin menyampaikan terimakasih sedalamdalamnya kepada semua pihak yang telah membantu sehingga penelitian ini dapat terselesaikan.

\section{DAFTAR PUSTAKA}

Jayakumar, R., Prabaharan, M., Sudheesh Kumar, P.T., Nair, S.V., Tamura, H. 2011. Biomaterials based on chitin and chitosan in wound dressing applications. Doi: 10.1016/j.biotechadv.2011.01.005.

Neto, C. G. T., Giacometti, J., Job, A., Ferreira, F., Fonseca, J., \& Pereira, M. 2005. Thermal analysis of chitosan based networks. Carbohydrate Polymers, 62(2), 97-103.

Rohindra, D.R., Ashveen V. Nand., Jagjit R. Khurma. 2004. Swelling Properties of Chitosan Hydrogel. The South Pacific Journal of Natural Science 22(1) 32.35 .
Erizal, Redja, I Wayan. 2010. Sintesis Hidrogel Superabsorben Polietilen Oksida-Alginat dengan Teknik Radiasi Gamma dan Karakterisasinya. Jurnal Ilmu Kefarmasian Indonesia, 8, 11-17.

Istiqomah, N. 2012. Pembuatan Hidrogel Kitosan-Glutaraldehid Untuk Aplikasi Penutup Luka Secara In Vivo. Skripsi, Program Studi Teknobiomedik FSAINTEK, Universitas Airlangga : Surabaya.

Widyatama, D. 2011. Efektifitas Kombinasi Glutaraldehid dan Didecil Dimetil Amonium Klorida Sebagai Desinfektan Terhadap Penurunan Jumlah Bakteri Pada Kandang Ayam Layer. Universitas Airlangga: Surabaya.

Jameela, S.R., Misra, A., Jayakrishnan, A. 1994. Crosslinked Chitosan Microsphere as Carries for Prolonged Delivery of Macromolecular Drugs. Journal of Biomaterial Science, Polymer Education, 6, 621-631.

$\mathrm{Hu}, \mathrm{H} .$, Xin, H.J., Hu, H., Chan, A., He, L. 2012. Lutaraldehyde-Chitosan and Poly (vinyl alcohol) Blends, and Fluorescence of Their Nano-Silica Composite Films. Carbohydrate Polymers, 91 (2013) : 305-313.

Andreas, H., In Gachter, R., and Muller, H. 1990. PVC Stabilizer and Plastics Additives Handbook. Germany : Hanser Publishers, Munich.

Yudi, Garnida. 2006. Respon Buah Durian Terolah Minimal Akibat Pengaruh Formulasi Bahan Edible Coating dan lama Penyimpanan Pada Suhu Beku. Disertasi Program Pascsarjana, Universitas Padjadjaran : Bandung.

Cerqueira, Miguel A., Alvaro M. Lima., dkk. 2009. Suitability of Novel Galactomannans as Edible Coatings for Tropical Fruits. Journal of Food Engineering 94 (2009) 372-378.

Van Vlack, L.H. 1991. Ilmu dan Teknologi Bahan. Edisi ke-5, Alih Bahasa : Japrie Sriati, Erlangga : Jakarta.

Wardhani, R.A.K. 2012. Sintesis dan Karakterisasi Bioselulosa-Kitosan Dengan Penambahan Gliserol Sebagai Plasticizer. Skripsi, Program Studi Fisika FSAINTEK, Universitas Airlangga : Surabaya. 
Baran, E.T., Mano, J.F., Reis, R.L. 2004. Starch-Chitosan Hydrogels Prepared by Reductive Alkylation Cross-linking. Journal of Materials Science: Materials in Medicine 15 (2004) 759765.

Singh, A., S.S. Narvi., P.K. Dutta N.D. Pandey. 2005. External Stimuli Response on a Novel Chitosan Hydrogel Crosslinked with Formaldehyde. Bull. Mater. Sci., Vol. 29 No. 3, June 2006, pp. 233-23, Indian Academy of Science 233.

Suptijah, P., Salamah, E., Sumaryanto, H., Purwaningsih, S., Santoso, J. 1992. Pengaruh Berbagai Isolasi Kitin Kulit Udang Terhadap Mutunya. Laporan Penelitian, Bogor: Fakultas Perikanan dan Ilmu kelautan, Institut Pertanian Bogor.

Baroni, P., Vieira, R.S., Meghetti, E., Silva, M.G.C., Beppu, M.M.. 2008. Evaluation of Batch Adsorption of Chromium Ions on Natural and Crosslinked Chitosan Membranes. Journal of Hazardous Materials, 152, 1155-1163.

Monteiro, O.A.C, Airoldi, C. 1999. Some Studies of Crosslinking ChitosanGlutaraldehyde Interaction in Homogeneous System. Int J Biol Macromol 26, 119-128.

Janjarasskul, T., Krochta, J.M. 2010. Edible Packaging Materials, The Annual Review of Food Science and Technology 1, 415-448.

McHugh, T.H., Aujard, J.F., and Krochta, J.M. 1994. Plasticized Whey Protein Edible Films: Water Vapor Permeability Properties. Journal of Food Science 59(2) : 416-419.

Harsunu, B.T. 2008. Pengaruh Konsentrasi Plasticizer Gliserol dan Komposit Khitosan dalam Zat Pelarut Terhadap Sifat Fisik Edible Film dari Khitosan. Skripsi, Program Studi Teknik Kimia FT, UI : Jakarta.

Kemalasari, E. 2010. Karakteristik Mikrobiologi dan Biodegradasi Edible Film Berbasis Pati Ubi Kayu. Tesis, Program Studi Kimia FMIPA, USU : Medan.
Park, K.R., and Nho, Y.C. 2001 Preparation and Characterization of Gelatin/Chitosan Hydrogel and PVP/Gelatin/Chitosan Hydrogel by Radiation. Kongop Hwahak, 12, 637642.

Krochta, J.M. 1994. Edible Coatings and Films to Improve Food Quality, Pennsylvania: Technomic Publising Co. Inc.

Svensson, B. Rene, Hansen, Philip, Hassenkam, Tue. 2011. Mechanical Properties of Human Patellar Tendon at the Hierarchial Levels of Tendon and Fibril. Journal of Applied Physics, 112:419-426.

Maganaris, C.N., Paul, J.P. 1999. In Vivo Human Tendon Mechanical Properties. Journal of Physiology 521.1: 307 313.

Leceta, I., Guerrero, K. 2012. Functional Properties of Chitosan-Based Films. Journal of Carbohydrate Polymers 93 (2013) 339-346.

Darni, Yuli et al. 2009. Peningkatan Hidrofobisitas dan Sifat Fisik Plastik Biodegradabel Pati Tapioka dengan Penambahan Selulosa Residu Rumput Laut Euchema Spinossum. Seminar Hasil Penelitian \& Pengabdian Kepada Masyarakat, Universitas Lampung : Lampung. 